\title{
Kejadian Infeksi Saluran Kemih di Ruang Rawat Inap Anak RSUD Dr. Zainoel Abidin Banda Aceh
}

\author{
Syafruddin Haris, * AnisahSarindah, ${ }^{* *}$ Yusni, ${ }^{* *}$ Raihan ${ }^{*}$ \\ *Departemen Ilmu Kesehatan Anak, RSUD Dr.Zainoel Abidin, Banda Aceh \\ **Fakultas Kedokteran Universitas Syiah Kuala,Darussalam, Banda Aceh
}

\begin{abstract}
Latar belakang. Infeksi saluran kemih (ISK) merupakan istilah umum untuk berbagai keadaan bertumbuh dan berkembang biaknya mikroorganisme dalam saluran kemih dalam jumlah yang bermakna.

Tujuan. Mengetahui kejadian dan kuman penyebab ISK pada anak rawat inap di RSUD Dr. Zainoel Abidin Banda Aceh.

Metode. Penelitian observasional dengan pengambilan sampel menggunakan sampel urin porsi tengah (midstream urine) dan kateterisasi

Hasil. Bakteri penyebab ISK pada anak di ruang rawat inap anak RSUD Dr.Zainoel Abidin Banda Aceh adalah bakteri Pseudomonas aeroginosa 4 (28,56\%) kemudian diikuti oleh Escherichia coli 3(21,43\%), Klebsiela sp $3(21,43 \%)$ dan Stafilokokus aureus 2 (14,29\%). Hasil uji sensitivitas pada setiap bakteri berbeda-beda. Bakteri yang diuji telah mengalami resistensi terhadap antibiotik golongan sefalosporin generasi I,II,III. Golongan meropenem masih sensitif terhadap bakteri Gram negatif batang, namun bakteri Gram positif kokus yaitu Stafilokokus aureus resisten terhadap antibiotik ini.

Kesimpulan. Bakteri penyebab ISK di ruang rawat inap anak yang terbanyak adalah Pseudomonas aeroginosa yang sensitif dengan antibiotik golongan meropenem. Sari Pediatri 2012;14(4):235-40.
\end{abstract}

Kata kunci: infeksi saluran kemih, kuman penyebab, sensitivitas antibiotik

I nfeksi saluran kemih (ISK) merupakan istilah umum untuk berbagai keadaan tumbuh dan berkembangnya bakteri dalam saluran kemih dengan jumlah yang bermakna. Pada dekade terakhir ini, morbiditas ISK pada bayi dan anak meningkat secara signifikan. ${ }^{1-3}$ Kejadi-

\footnotetext{
Alamat korespondensi:

Dr. Syafruddin Haris, Sp.A. Departemen Ilmu Kesehatan Anak, RSUD Dr.Zainoel Abidin, Banda Aceh. Jl. Tgk. Syech Muda Wali No.6, Banda Aceh. Telp. (0651) 32444, Fax. (0651) 31995. E-mail: harissyafruddin@ idai.or.id
}

an ISK diperkirakan terjadi pada $1 \%$ anak laki laki dan $3 \%-8 \%$ anak perempuan. ${ }^{2}$ Montini $\mathrm{dkk},{ }^{4}$ menambahkan bahwa sekitar 7\% sampai $8 \%$ anak perempuan dan $2 \%$ anak laki-laki mengalami ISK selama 8 tahun pertama kehidupannya.

Pada bayi dan anak-anak ISK perlu mendapat perhatian khusus karena selalu disertai dengan gejala klinis yang amat samar dan sering tidak spesifik dan cara memperoleh sampel urin yang invasif serta fasilitas diagnostik yang kurang pada negara berkembang. Selain itu ISK pada anak berisiko 
terhadap kerusakan ginjal yang berlanjut menjadi pielonefritis (radang ginjal) dan berdampak pada gagal ginjal di usia dewasa. ${ }^{5,6}$ Di Eropa, 20\% kasus gagal ginjal yang harus menjalani dialisis maupun transplantasi ginjal disebabkan oleh ISK pada masa anak-anak. ${ }^{7,8}$

Infeksi saluran kemih dapat disebabkan oleh berbagai macam mikroorganisme seperti bakteri, virus, dan jamur, tetapi yang terbanyak adalah bakteri. ${ }^{6}$ Menurut WHO bakteri utama terkait ISK pada anak anak di negara berkembang adalah organisme Gram negatif, seperti Escherichia coli. ${ }^{5}$ Pada rumah Sakit Cipto Mangunkusumo (RSCM), ditemukan 3 jenis kuman pada pasien ISK anak yaitu Eschericia coli, Enterobacter aerogenes dan Acinetobacter calcoaceticus, ${ }^{10}$ sedangkan di RSUP H. Adam Malik, Medan kejadian ISK banyak dijumpai pada kelompok anak anak (0-15) tahun dengan kuman penyebab Enterobacter $s p(23,7 \%)$, Pseudomonas sp (18,3\%) dan Eschericia coli $(17,7 \%) .{ }^{11}$

Pada dekade terakhir ini resistensi kuman patogen penyebab ISK terhadap satu atau lebih antibiotik semakin meningkat, ${ }^{12}$ seperti ampisilin dan amoksisilin terhadap bakteri Eschericia coli. ${ }^{13}$ Begitu juga terhadap amikasin $(32,5 \%)$, nitrofurantoin $(26,7 \%)$ dan imipenem $(3,7 \%)$ telah resisten terhadap Enterobacteriaceae secara in vitro. ${ }^{14}$ Selain itu antibiotik penisilin, sefuroksim, dan sulfametoksazol juga telah resisten terhadap kuman penyebab ISK. ${ }^{11}$ Pemberian terapi yang tepat perlu didukung oleh hasil kultur urin dan uji sensitivitas terhadap antibiotik.

Pola dan uji sensitivitas kuman terhadap antibiotik sangat penting dilakukan, dimaksudkan untuk identifikasi dan tata laksana pada anak yang mempunyai risiko kerusakan ginjal, untuk mencegah intervensi yang mahal sehingga penelitian tentang pola dan sensitivitas kuman terhadap antibiotik harus selalu baru..$^{15}$

Dua parameter penting ISK antara lain jumlah leukosit dan bakteri dalam urin. Jumlah leukosit yang dianggap bermakna adalah $>5 /$ lapang pandang besar (LPB). Apabila didapat leukosituri yang bermakna, perlu dilanjutkan dengan pemeriksaan kultur. ${ }^{16}$

Sampai saat ini pemeriksaan urinalisis dilakukan jika dicurigai ISK. Untuk kasus di luar sering diabaikan. Kenyataannya pada kasus lain kejadian ISK sering dijumpai. Berdasarkan uraian di atas, diperlukan penelitian untuk mengetahui bagaimana kejadian ISK pada anak yang dirawat inap di RSUDZA pada saat ini.

\section{Metode}

Penelitian deskriptif observasional yang dilakukan pada bulan Januari- Maret 2012, di ruang rawat inap anak bangsal Seruni satu RSUDZA. Populasi adalah semua pasien baru pada bangsal serune 1 atau telah dirawat 48 jam. Pengambilan sampel dilakukan dengan metode accidentally sampling. Sampel urin diperoleh dari kateter dan urin porsi tengah (midstream urine) ditampung dalam wadah bermulut lebar dan steril selanjutnya dilakukan pemeriksaan pada laboratorium RSUD Zainoel Abidin.Jika jumlah lekosit urin $>5 / \mathrm{LPB}$ dilakukan pemeriksaan kultur urin. Diagnosis ISK apabila biakan air kemih secara kuantitatif menunjukkan sejumlah kuman yang dianggap bermakna $\left(10^{5} \mathrm{koloni} / \mathrm{ml}\right) .{ }^{12}$ Jika pasien atau orangtua menolak pemakaian kateter dikeluarkan dari penelitian ini.

Metode pengamatan dilakukan secara langsung terhadap hasil kultur dan identifikasi kuman dari urin anak dengan ISK, dilanjutkan dengan uji sensitivitas antibiotik.

Uji sensitivitas antibiotik dilakukan dengan metode difusi Kirby Bauer agar menggunakan cakram antibiotik yang distandarisasikan. Diameter daerah bening diukur dengan skala millimeter dan menggunakan tabel Clinical Laboratory Standars Institute (CLSI) 2007. Sensitivitas kuman terhadap antibiotik ditentukan oleh diameter zona hambat yang terbentuk dalam millimeter $(\mathrm{mm})$. Semakin besar diameter maka semakin terhambat pertumbuhan kuman. Hasil uji ini dirujuk dengan tabel CLSI untuk menentukan sensitif (S), intermediet (I) atau resisten $(\mathrm{R}) .^{17}$

\section{Hasil}

Selama penelitian, diperoleh 91 sampel urin terdiri atas 49 anak laki laki dan 42 perempuan. Anak jumlah leukosit urin $>5$ leukosit/LPB atau leukosituria 34 orang terdiri atas 17 laki-laki dan 17 perempuan, dan anak dengan leukosit urin <5 LPB 57 anak. Sampel sangkaan ISK tertinggi terdapat pada kelompok umur 4-6 tahun $(20,6 \%)$. Karakteristik pasien anak pada Tabel 1

Hasil isolasi mikroorganisme, dari 34 sampel urin dengan leukosit $>5 / \mathrm{LPB}$ adalah bakteri patogen 14 $(41,2 \%)$, bakteri non patogen dan jamur $6(17,6 \%)$, dan $14(41,2 \%)$ tidak ditemukan pertumbuhan 
mikroorganisme. Hasil pertumbuhan mikroorganisme tertera pada Tabel 1.

Berdasarkan data pada Tabel 2, anak dengan urin mengandung bakteri patogen dilakukan identifikasi

Tabel 1. Karakteristik sampel

\begin{tabular}{lcc}
\hline Sampel & Jumlah & Persentase \\
\hline Jenis kelamin & & \\
Laki-laki & 17 & 50 \\
Perempuan & 17 & 50 \\
Umur (tahun) & & \\
$1-3$ & 6 & 17,65 \\
$4-6$ & 7 & 20,59 \\
$7-9$ & 6 & 17,65 \\
$10-12$ & 6 & 17,65 \\
$13-15$ & 4 & 11,76 \\
$16-18$ & 5 & 14,70 \\
\hline Total & 34 & 100,00 \\
\hline
\end{tabular}

kuman, dan terdapat pertumbuhan bakteri patogen pada media, sebagian besar 12 isolat $(85,7 \%)$ berupa bakteri batang Gram negatif dan 2 (14,3\%) bakteri kokus Gram positif. Pada kultur urin, teridentifikasi 5 spesies bakteri, terdiri dari bakteri Pseudomonas aeroginosa 4 (28.56\%) kemudian diikuti oleh Escherichia coli 3 (21,43\%), Klebsiela sp 3 (21,43\%) Proteus mirabilis 2 (14,3\%), dan Stafilokokus aureus 2 (14,29\%).

Bakteri Pseudomonas aeruginosa merupakan yang terbanyak ditemukan. Sebaran spesies bakteri patogen tersebut tertera pada Gambar 1.

Hasil uji sensitivitas antibiotik menunjukkan bahwa Pseudomonas aeruginosa telah resisten terhadap tikarsilin, seftazidim, sefotaksim, dan seftriakson dan masih sensitif $100 \%$ terhadap siprofloksasin dan meropenem.

Hasil uji sensitivitas antibiotik terhadap bakteri Escherichia coli menunjukkan bahwa, bakteri

Tabel 2. Diagnosis pasien rawat yang tersangka ISK

\begin{tabular}{lcl}
\hline \multicolumn{1}{c}{ Diagnosis awal } & Jumlah & \multicolumn{1}{c}{ Hasil kultur } \\
& leukosit/LPB & \\
\hline Habdomiosarkoma & Penuh & Pseudomonas aeruginosa \\
Sirosis hepatis + Thalasemia $\beta$ mayor & $8-10$ & Pseudomonas aeruginosa \\
Meduloblastoma & $12-15$ & Pseudomonas aeruginosa \\
Demam berdarah dengue grade III + Tuberkulosis paru & $6-8$ & Pseudomonas aeruginosa \\
Hidronefrosis grade II & $10-12$ & Escherichia coli \\
Demam berdarah dengue & $6-8$ & Escherichia coli \\
Pielonefritis & $8-10$ & Escherichia coli \\
Sirosis hepatis + Thalassemia $\beta$ mayor & $10-12$ & Klebsiella sp \\
Bronkopneumonia & $6-8$ & Klebsiella sp \\
Demam berdarah dengue & $6-8$ & Klebsiella sp \\
Sirosis hepatis & $8-10$ & Proteus mirabilis \\
Demam berdarah dengue & $8-10$ & Proteus mirabilis \\
Fibrosarkoma & $10-12$ & Stafilokokus aureus \\
Demam berdarah dengue & $6-8$ & Stafilokokus aureus \\
\hline
\end{tabular}

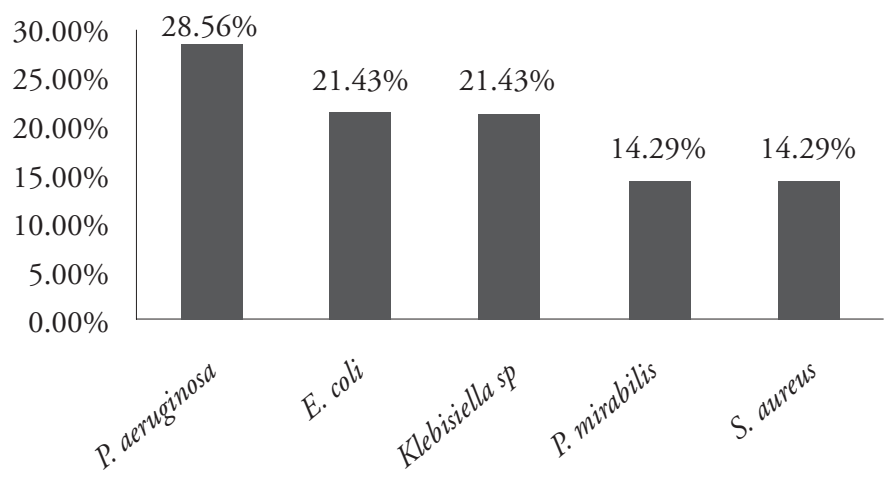

Gambar1. Jenis bakteri penyebab infeksi saluran kemih

Persentase bakteri penyebab ISK 
Syafruddin Haris dkk: Kejadian infeksi saluran kemih

Tabel 3. Kepekaan antibiotik terhadap bakteri Pseudomonas aeruginosa

\begin{tabular}{lcccccc}
\hline & \multicolumn{5}{c}{ Tingkat sensitivitas antibiotik } \\
\cline { 2 - 7 } Antibiotik & \multicolumn{2}{c}{ Sensitif } & \multicolumn{2}{c}{ Resisten } & \multicolumn{2}{c}{ Total } \\
\cline { 2 - 7 } & $\mathrm{n}$ & $\%$ & $\mathrm{n}$ & $\%$ & $\mathrm{n}$ & $\%$ \\
\hline Seftazidim & 3 & 75 & 1 & 25 & 4 & 100 \\
Sefotaksim & 1 & 25 & 3 & 75 & 4 & 100 \\
Seftriakson & 1 & 25 & 3 & 75 & 4 & 100 \\
Siprofloxasin & 4 & 100 & - & 0 & 4 & 100 \\
Tobramisin & 3 & 100 & - & 0 & 3 & 100 \\
Meropenem & 3 & 100 & - & 0 & 3 & 100 \\
Tikarsilin & - & 0 & 2 & 100 & 2 & 100 \\
Gentamisin & 2 & 100 & - & 0 & 2 & 100 \\
Tikarsilin-asam klavulanat & 1 & 100 & - & 0 & 1 & 100 \\
\hline
\end{tabular}

Tabel 4. Kepekaan antibiotik terhadap bakteri Escherichia coli

\begin{tabular}{|c|c|c|c|c|c|c|}
\hline \multirow{3}{*}{ Antibiotik } & \multicolumn{6}{|c|}{ Tingkat sensitivitas antibiotik } \\
\hline & \multicolumn{2}{|c|}{ Sensitif } & \multicolumn{2}{|c|}{ Resisten } & \multicolumn{2}{|c|}{ Total } \\
\hline & $\mathrm{n}$ & $\%$ & $\mathrm{n}$ & $\%$ & $\mathrm{n}$ & $\%$ \\
\hline Seftazidim & & 0 & 3 & 100,0 & 3 & 100,0 \\
\hline Kloramfenikol & & 0 & 3 & 100,0 & 3 & 100,0 \\
\hline Kotrimoksazol & & 0 & 3 & 100,0 & 3 & 100,0 \\
\hline Tobramisin & 1 & 33,3 & 2 & 66,7 & 3 & 100,0 \\
\hline Siprofloxasin & & 0 & 3 & 100,0 & 3 & 100,0 \\
\hline Amoksisilin-klav & & 0 & 2 & 100,0 & 2 & 100,0 \\
\hline Sodium sefuroksim & & 0 & 2 & 100,0 & 2 & 100,0 \\
\hline Seftriakson & & 0 & 2 & 100,0 & 2 & 100,0 \\
\hline Meropenem & 2 & 100,0 & 2 & 0 & 2 & 100,0 \\
\hline Tetrasiklin & & 0 & 1 & 100,0 & 2 & 100,0 \\
\hline Sefotaksim & & 0 & 1 & 100,0 & 1 & 100,0 \\
\hline Sefalotin & & 0 & & 100,0 & 1 & 100,0 \\
\hline
\end{tabular}

Escherichia coli telah resisten terhadap antibiotik golongan sefalosporin yaitu seftazidim, sefalotin, sodium sefuroksim, sefotaksim, seftriakson. Antibiotik lain yang juga mengalami resistensi terhadap bakteri Escherichia coli yaitu amoksisil-klavulanat, kloramfenikol, kotrimoksazol, tobramisin, tetrasiklin, dan siprofloksasin. Meropenem dan juga tobramisin masih cukup sensitif terhadap bakteri Escherichia coli.

\section{Pembahasan}

Kami mendapatkan 91 pasien baru yang telah dirawat 48 jam melakukan pemeriksaan urinalisis, di antaranya 34 orang hasil leukosit urin $>5 / \mathrm{LPB}$. Dapat dikatakan bahwa pemeriksaan urinalisis memang perlu dilakukan pada setiap pasien yang dirawat inap karena tidak tertutup kemungkinan disertai ISK. Kepustakaan menyebutkan bahwa pada ISK dapat terjadi peningkatan jumlah leukosituria yang bermakna yaitu $>5 / \mathrm{LPB}$ atau bakteriuria. Dengan dasar tersebut kami dapat melanjutkan dengan pemeriksaan kultur urin. ${ }^{6,18}$ Pada penelitian kami hasil kultur urin dari 34 sampel urin pasien anak yang mengandung leukosit $>5 / \mathrm{LPB}, 14$ sampel $(41,2 \%)$ bakteri patogen terisolasi serta bakteri non patogen dan jamur $6(17,6 \%)$, dan $14(41,2 \%)$ tidak ditemukan pertumbuhan mikroorganisme.

Deteksi bakteri merupakan baku emas untuk 
diagnosis ISK. Pada penelitian kami didapatkan $>5$ leukosit/LPB dan apabila tidak terdapat bakteri bermakna maka dianggap bukan ISK. Walaupun demikian di dalam literatur lain disebutkan bahwa tidak adanya leukosituria tidak menyingkirkan ISK karena bakteria dapat juga terjadi tanpa leukosituria. Hal tersebut telah dibuktikan dari beberapa penelitian, salah satunya Riccabona ${ }^{2}$ menyatakan bahwa dari pemeriksaan urinalisis yang normal didapat 22\% spesimen positif tumbuh kuman. Sayangnya pada penelitian kami apabila leukosit <5/LPB tidak dilanjutkan dengan pemeriksaan kultur urin.

Bakteri Pseudomonas aeruginosa merupakan bakteri terbanyak penyebab ISK pada anak yang dirawat di ruang rawat inap anak RSUDZA Banda Aceh. Berbeda dengan penelitian lain yang menyatakan Escherichia coli banyak dijumpai yaitu 63\%-86\%., Bakteri Pseudomonas aeruginosa yang tinggi ditempat kami tidak dapat disimpulkan dengan pasti. Sebagian kasus yang diambil dalam 3 bulan penelitian memang terdapat pasien dengan keganasan yang diketahui telah mengalami penurunan daya tahan tubuh atau kemungkinan lain karena bakteri tersebut telah berkoloni dengan lingkungan di rumah sakit (seperti peralatan medis, udara, dan air) sebagai bakteri nosokomial, sehingga dapat menyebabkan infeksi pada pasien rawat inap. Menurut Boel ${ }^{17}$ infeksi dari bakteri Pseudomonas aeruginosa menjadi masalah serius pada pasien rumah sakit yang menderita kanker, fibrosis kistik, dan luka bakar. Angka fatalitas pasien tersebut mencapai 50\%. Namun demikian, kami belum dapat menarik kesimpulan mengenai hubungan antara penyakit tersebut dengan tingkat kejadian infeksi saluran kemih pada anak di ruang rawat inap anak RSUDZA.

Isolat bakteri Pseudomonas aeruginosa terlihat sensitif terhadap siprofloxasin dan antibiotik tobramisin, dan meropenem. Siprofloksasin merupakan antibiotik golongan fluoroquinolone terkuat daya antibakterinya terhadap Pseudomonas aeruginosa dibandingkan dengan antibiotik lain, untuk pemakaian pada anak obat tersebut tidak direkomendasikan. ${ }^{18}$ Sedangkan pada penelitian di Laboratorium Mikrobiologi Klinik FKUI menunjukkan sensitivitas bakteri Pseudomonas aeruginosa telah mengalami resistensi terhadap siprofloksasin. Pseudomonas aeruginosa tidak boleh diobati dengan terapi obat tunggal (untuk golongan penisilin dan sefalosporin) karena tingkat keberhasilan rendah dan bakteri dengan cepat jadi resisten. ${ }^{17}$ Sedangkan pada penelitian kami bakteri Pseudomonas aeruginosa telah mengalami resistensi terhadap golongan sefalosporin yaitu sefotaksim dan seftriakson. Resistensi dapat terjadi akibat bakteri mensentesis enzim yang dapat mengubah zat aktif menjadi tidak aktif sehingga terjadi resistensi tehadap penisilin dan sefalosporin. Bakteri tersebut menghasilkan enzim penisilinase yang mampu memecah cincin beta laktam, penisilin diubah menjadi penicilloid acid yang tidak aktif, demikian pula sefalosporin didegradasi oleh beta laktamase. ${ }^{19}$

Hampir semua antibiotik yang diuji pada bakteri Escherichia coli mengalami resistensi kecuali untuk meropenem. Hasil yang sama juga terdapat dalam penelitian Istanto ${ }^{20}$ yang dilakukan di RS Dr. Kariadi Semarang bahwa meropenem memiliki tingkat kepekaan 100\% terhadap bakteri Escherichia coli. Antibiotik lain yang juga masih sensitif terhadap Escherichia coli adalah tobramycin (33,3\%). Prais $\mathrm{dkk}^{5}$ menunjukan Escherichia coli resisten terhadap antibiotik golongan sefalosporin generasi ke-3 pada anak yang di rawat di rumah sakit dengan ISK tetapi hanya yang diberikan profilaksis antibiotik, sedangkan penelitian kami selain masih cukup singkat yang memang telah diketahui bahwa pemakaian dari setiap generasi sefalosporin cukup luas dipakai di rumah sakit ini.

Penelitian Ferdani ${ }^{21}$ menemukan hasil yang sama bahwa antibiotik meropenem masih memiliki kepekaan 100\%, namun berbeda dengan antibiotik siprofloksasin yang telah resisten $100 \%$ memang diketahui bahwa pemakaian obat tersebut pada pasien dewasa cukup luas dipakai.

Antibiotik golongan sefalosporin generasi ke-3 telah digunakan secara luas pada pengobatan berbagai penyakit infeksi. Hal tersebut disebabkan karena spektrum aktivitas antibakteri yang luas, mencakup bakteri Gram negatif dan Gram positif. Namun demiakian risiko berkembangnya resistensi akibat penggunaan yang terlalu luas perlu dipertimbangkan. Pengetahuan tentang pola kepekaan kuman di rumah sakit sangat diperlukan untuk digunakan sebagai acuan dalam penggunaan antibiotik. ${ }^{7}$ Di tempat kami penelitian seperti ini khususnya di rawat inap anak RSUDZA belum dapat dilaksanakan, terkendala dengan prosedur pemeriksaan dan pengambilan sampel urin yang sulit. Diharapkan ke depan dapat diketahui pola kepekaan kuman karena sangat bermanfaat 
untuk menetapkan kebijakan perputaran penggunaan antibiotik sebagai salah satu upaya meminimalkan kejadian resistensi.

Disimpulkan bahwa bakteri penyebab ISK di ruang rawat anak terbanyak adalah Pseudomonas aeroginosa yang sensitif terhadap antibiotik golongan meropenem. Penelitian lanjutan perlu dilakukan secara berkala dengan jangka waktu yang lama untuk dapat memantau pola kuman dan sensitivitas antibiotik pada anak pasien ISK di RSUDZA.

\section{Daftar pustaka}

1. Lutter SA, Currie ML, MitzLB, Greenbaum LA. Antibiotic resistance patterns in children hospitalized for urinary tract infections. Archs Pediatr Adolesc Med 2005;159:924-8.

2. Riccabona M. Urinary tract infections in children.Curr Opin Urol 2003;13:59-62.

3. Kher KK, Leichter HE. Urinary tract infection. Dalam: Kher KK, Makker SP, penyunting, Clinical Pediatric Nephrology, NewYork; McGraw-Hill;1992.h.277-321.

4. Montini G, Kjell T, Ian H. Febrile urinary tract infections in children.N Engl J Med 2011;365:239-50.

5. Prais D,Straussberg R, Avitzur Y, Nussinovitch M, Harel L, Amir J. Bacterial susceptibility to oral antibiotics in community acquired urinary tract infection. Archs Dis Child 2003:88:215-8.

6. Ladhani S, Gransden W. Increasing antibiotikresistance among urinary tract isolates. Archs Dis child 2003: 88:444-5.

7. Bensman A, Dunand O, Ulinski T. Urinary tract infection. Dalam: Avner ED, Harmon WE, Niaudet P, Yoshikawa $\mathrm{N}$, penyunting. Pediatric Nephrology. edisi ke-6. Berlin Heidelberg: Springer-Verlag; 2009.h.1229-310

8. Wiswell T. The prepuce, urinary tract infections, and the consequences. Pediatrics 2000;105: 860-62.

9. Miesien. Profil infeksi saluran kemih pada anak di Rumah
Sakit Cipto Mangunkusumo[tesis]. Jakarta: Fakultas Kedokteran Universitas Indonesia,2005.

10. San, NM. Gambaran pola kuman dan sensitifitasnya terhadap antibiotik[abstrak]. Medan: Fakultas Kedokteran Universitas Sumatera Utara,2011.

11. Samirah, Darwati, Windarwati, Hardjoeno. Pola dan sensitivitas kuman di penderita infeksi saluran kemih. Indones J Clin Path Med Lab 2006;12:110-3.

12. Taneja N, Chatterjee SS, Singh M, Singh S, Sharma M. Indian pediatric urinary tract infections in a tertiary care center fromNorth India. J Med Res 2010;131:101-5.

13. Hellerstain S. Recurrent urinary tract infection in children. Pediatr Infect Dis 2006;1:271-81

14. Mirawati T, Karuniawati A, Ningsih I KA, Tjampakasari CR, Hutabarat T dkk. Hasil uji resistensi bakteri terhadap berbagai antibiotik di laboratorium mikrobiologi klinik FK-UI. Jakarta: Laboratorium Mikrobiologi Klinik FKUI;2004.

15. Matthew A, Bush K, Cockerill FR, Dudley MN, Eliopoulos GM, Hardy DJ, dkk. Performance standards for antimicrobial susceptibility testing. Dalam: seventeenth informational supplement. Pennsylvania: Clinical Laboratory Standard Institute 2007;27:1:1-53.

16. Boel T. Infeksi saluran kemih dan kelamin. Medan: USU digital library,2004.

17. Setiabudy R. Antimikroba. Dalam: Farmakologi dan terapi. Edisi V. Jakarta: FKUI, 2007.

18. Refdanita, Maksum R, Nurgani A, Endang P. Pola kepekaan kuman terhadap antibiotik di ruang rawat intensif rumah sakit Fatmawati Jakarta tahun 2001 -2002. Makara,Kesehatan 2004;8:41-8

19. IstantoT. Faktor risiko pola kuman dan tes kepekaan antibiotik penderita infeksi saluran kemih di RS Dr.Kariadi Semarang tahun 2004-2005.skripsi.Fakultas kedokteranUniversitas Diponegoro. Semarang.2006.

20. Ferdani W. Pola bakteri dan sensitivitas antibiotik pada penderita infeksi saluran kemih rawat inap bedah RSUD Dr. Zaenoel Abidin Banda Aceh [skripsi]. Banda Aceh: Fakultas Kedokteran Universitas Syiah Kuala,2011. 